\title{
New Clause in Bank Credit Agreement in Relation to Consumer Protection Act (Study on PT. Bank Negara Indonesia, Tbk. Denpasar Branch)
}

\author{
Komang Yustika Dewi Suryaningsih'1 \& A.A.A. Ngr. Tini Rusmini Gorda ${ }^{2}$ \\ Undiknas Pasca Sarjana, Denpasar Bali \\ kmyustikadewi@gmail.com¹ \& tinirusmini@undiknas.ac.id²
}

\begin{tabular}{|c|}
\hline Published: 02/03/2021 \\
\hline How to cite (in APA style): \\
\hline $\begin{array}{l}\text { Suryaningsih, K. Y. D., \& Gorda, A. (2021). New Clause in Bank Credit Agreement in Relation to Consumer Protection } \\
\text { Act (Study on PT. Bank Negara Indonesia, Tbk. Denpasar Branch). Jurnal Hukum Prasada, 8(1), 1-7. doi: } \\
\text { https://10.22225/jhp.8.1.2761.30-36 }\end{array}$ \\
\hline
\end{tabular}

\begin{abstract}
Credit agreement in standard form which is being made unilaterally by the bank until present is still becoming a special legal issue in agreement field of civil law. In addition, viewed from the side of the agreement it is also against consumer protection law as set in Consumer Protection Act. Problem formulation of is divided into namely regarding the existence of standard clause in bank agreement if associated with Article 18 of Consumer Protection Act and legal consequence of standard clause in credit agreement associated with consumer protection. This study aims to identify the presence of standard clause in banking agreement if related with Article 18 of Consumer Protection Act and legal consequence to the standard clause in credit contract is associated with consumer protection. The research is a juridical empirical. The location is on PT. Bank Negara Indonesia in Denpasar city. The author is guided by laws and regulations related with public fact, that is first problem formulation is analyzed from balancing principle and next the second problem formulation is from consumer protection theory. The result shows that the implementation of the provision tends to protect the bank as businesses. Moreover, the legal consequence of Bank BNI's credit contract which does not meet the provision will result in null and void.
\end{abstract}

Keywords: Bank Credit Agreement; New Clause; Standard Contract

\section{INTRODUCTION}

In the progression, credit has provided various conveniences in economic traffic both in rural and urban area, in trading, transportation, business development, housing and settlement construction and in capital market traffic. Credit has a very important role in economic development since credit is a development support and the veins for entrepreneurs. Any individual or enterprise who attempts to increase consumptive and productive needs badly needs funding and one of them from credit considering the capital owned by enterprise or individual usually incapable to support his business development (Subekti, 1991). The Law Number 8 year 1999 regarding Consumer Protection (hereinafter referred to as UUPK) also interrelated, especially in the case of legal protection for bank's client as a consumer. Among others is the presence of credit agreement or bank financing which is as a standard contract. In terms of form, bank credit agreement in general uses the form of standard contract. Standard contract is the agreement which its clauses is standardized by its users and other parties, basically it does not have a chance to be negotiated or amended (Kristiyanti, 2019). 
The importance of banking institutions' existence in one side provide very high risk for banks and in the other side provide benefit for public as fund user's clients. This risk that later causing bank to always using contract as the basis for its transaction activities. In contrary, the clients often unconsciously suffer loss due to the contract made by the bank. This loss is related to the inclusion of standard clause in the agreement between bank and client.

Based on The Law Number 8 of 1999 regarding Consumer Protection (UUPK), a ban has been set regarding the inclusion of standard clause in every document and/or agreement if containing about the transfer of businesses' responsibility (Article 18), however in reality still often encountered.

Standard contract circulating in public is seen from the viewpoint of many parties still in many aspects detrimental to people with the clause containing in the contract. The content of standard contract in general is biased because it tends to benefit the contract maker. The other party has no other choice except to merely accept the terms submitted by the contract maker since the party who makes the contract has better bargaining power or position. Legal protection for debtor client as a consumer is only regarding provisions and procedures for the inclusion of standard contract. Since in reality generally the standard contract shows how low the bargaining position for debtor. Despite Consumer Protection Act has been enforced, but in Indonesia the standard contract which its substance includes clause that burdens the consumers in reality even has penetrated up to banking realm. Credit contract in standard form made unilaterally by the bank until now still becomes a special legal issue in contract field of civil law. In addition, in terms of its agreement side it also against consumer protection law as has been set in Consumer Protection Act, so it is very interesting to conduct a research. Therefore, this study aims to identify the presence of standard clause in banking agreement if related with Article 18 of Consumer Protection Act and legal consequence to the standard clause in credit contract is associated with consumer protection.

\section{LITERATURE REVIEW}

Credit is derived from Greek language (credere) which means trust. Therefore, the basis of credit is trust (Suyatno \& Chalik, 2007). Trust from the creditor to the debtor which means Creditor trusts that Debtor will return the debt along with interest in accordance with the agreement by both parties, meanwhile for credit acceptor it means that he/she accepts the trust, so that he/she has an obligation to pay back the debt in accordance with its time frame. So it can be concluded that any credit granting only can happen if within it contained the trust of individual/institution that provides credit to person who accepts credit. 2005):

The meaning of bank credit contains credit elements consist of the followings (Sutarno,

1. Trust, namely the confidence from credit provider that the benefit that it provides whether in the form of money, goods, or service, will really be return back in certain period in the future.

2. Deadline, namely a period separating between benefit being provided and benefit return that will be received in the future. In this time element contains the meaning of agio value of money, namely the money now present will be higher in value compared to the money that will be received in the future.

3. Degree of risk, namely the risk level which will be faced as the result of time period that separating between benefit being provided and benefit return that will be received in the future. The longer credit is given then the higher the degree of risk, this is what causes the risk element. With the presence of risk element, so collateral appears in credit granting.

Standard contract is an agreement made in standard form or printed in large quantities with blank form for some parts which becomes transaction objects, such as the amount of transaction value, type and number of goods that issues it, not giving a chance for other parties to make negotiation regarding what is being agreed to be outlined in a contract. 
Some people state that standard contract is said as a contract or agreement which being made by all parties regarding something that has been defined by standard and outlined in written (Miru \& Yodo, 2008). The word standard means that the benchmark being used as a parameter or guidance for any consumer who has been in legal relationship with businesses, which is standardized in standard contract including the model, formulation, and size (Muhammad, 2006). The form of standard contract with standard terms generally consists of (Nasution, 2002):

1) In the form of document.

It is an agreement which its concept has been prepared beforehand by one of the parties. Normally it contains special terms either with respect to contract implementation, related to certain issues and/or termination of an agreement.

2) In the form of terms in the agreement.

This contract can also in other form such as contained in various receipts, receipt form or sales form, certain cards, in billboards put inside the room. Credit contract is identified with money loan and borrow agreement which has special properties. It means that loan and borrow agreement happens between bank and debtor, in which debtor will pay back the loan after certain period of time (Rahmatullah, 2015).

Consumer protection has a broad meaning that is including protection to consumers, goods, and service. The sentence which says "every effort to warrant legal certainty", is expected as a stronghold to negate arbitrary action that is detrimental to businesses just for the sake of consumer protection interest. In accordance with Article 1 number 1 the Law Number 8 year 1999 regarding Consumer Protection which states that "Consumer protection is any effort that warrants legal certainty to provide protection to consumer".

\section{METHOD}

Type of research being used in this thesis is juridical empirical that is in studying the issue, the author is guided by the provisions of laws and regulations related to problem formulation being raised which later is associated with the facts in society through research in the field which takes location at PT. Bank Negara Indonesia in Denpasar city. Legal research regarding the enforcement or implementation of legal provision in every certain legal event happened in society in order to achieve the expected goal.

Type of data being used: Primary Data which is research material in the form of empirical facts as human behavior or the result of human behavior, both in verbal form of real behavior as well as behavior that are driven in various behavior results or records/archives of primary data acquired directly from research location that is by direct interview and direct observation in the field. Secondary data is data which is acquired from information or knowledge acquired indirectly among others from legal material which provides explanation regarding primary legal material in the form of literatures concerning of this research, including legal science books, the works from legal circles, internet search, journal, newspaper, and papers.

Data Sampling Technique: Primary data acquisition from field research can be done either through observation, interview or questionnaire distribution. Meanwhile secondary data is data acquired through literature, by studying, examining, and processing literature, laws and regulations, articles or writings related to the issue being studied.

\section{RESULT AND DISCUSSION}

\section{a. The presence of standard clause in banking agreement if related with Article 18 of Consumer Protection Act.}

Regulation regarding the Inclusion of Standard Clause in Consumer Protection Act, the balancing position between all parties in making an agreement is an important factor, in which all parties discussing agreement content until the contract has been agreed based on conformity of wish from each party. Modernization progress in society with practical and efficient rationale when the contract is made unilaterally without being negotiated beforehand, the result is that consumer is in weaker position due to necessity, and he/she 
will accept as such the agreement with clauses being standardized beforehand by businesses. As referred to in Consumer Protection Act, the objective of consumer protection is to protect the interest of debtor client in the banking credit agreement. In the process of credit usually the position of debtor is always under creditor, so that debtor client does not have enough bargaining power to risking his/her rights. The creation of credit agreement between client as debtor and the bank as creditor, generally the agreement has been made in standard form by the bank. The standard clause is applied with efficiency reason, since to make the same agreement each time particularly is considered inefficient (Sastrawidjaja, 2005). Consumer protection is the issue of human interest. To materialize consumer protection is to materialize the relationship of various dimensions which one another has relationship and interdependence between consumers, businesses and government (Syawali \& Imaniyati, 2000).

Provision regarding the inclusion of standard clause based on the Law No. 8 regarding Consumer Protection outlined in Article 18 namely:

1. Businesses in offering his goods/service intended to be traded is prohibited to make or include standard clause in each document and/or agreement if:

a. Stating about transfer of responsibility of the businesses;

b. Stating that businesses is entitled to reject the return of goods that has been purchased by the consumer;

c. Stating that businesses is entitled to reject the return of money that has been paid on goods and/or service being purchased by the consumer;

d. Stating of power granting from the consumer to businesses both directly and indirectly to do all unilateral actions related to the goods being purchased by consumer on an installment basis.

e. Setting about verification over the loss of usage of goods or service benefit being purchased by the consumer;

f. Granting the rights to the businesses to reduce service benefit or decrease the asset of consumer which becomes the object of sale and purchase of the service.

g. Stating that the consumer is subject to the regulation in the form of new rules, addendum, extension and/or further amendment which being made unilaterally by businesses within the period of consumer makes use of the service that he/she purchases;

h. Stating that consumer grants the power to businesses for the imposition of mortgage rights, lien, or collateral rights to the goods being purchased by the consumer on an installment basis.

Legal relationship between bank and client as debtor is written in an agreement known by banking realm with the term "credit agreement". Position of all parties in a credit is set in an agreement, and in the agreement is set the rights and obligations of all parties as agreement's subjects.

Implementation of Provision in Article 18 of Consumer Protection Act related to bank credit agreement in the form of standard contract at bank BNI. BNI's Credit standard Contract in consensual aspect is a reciprocal agreement. One of the party acquires the rights from this agreement, and also receives obligations from the rights that he/she acquires.

In this discussion the author used balancing principle since in this case the adjustment of interest rate in Bank BNI's credit contract tends to be imbalance.

Badrulzaman (1991) suggested formulation regarding the trait of standard contract which tended to be imbalance as follows:

1. The content was set unilaterally by the creditor who had position relatively stronger than the debtor;

2. The debtor was completely not involved to determine the content of the contract;

3. Urged by his/her needs, the debtor was forced to accept the contract;

4. The form was in writing, prepared beforehand en masse or individually. 
Based on the trait of standard contract mentioned above, so surely BNI's credit contract is a standard contract, in which the content or clauses of that credit contract has been standardized and outlined in the blank form. Debtor client just signs his/her signature if he/she is willing to accept the agreement's content, does not give any chance to the prospective client.

In Bank BNI's credit contract some clauses that can be considered susceptible if not to say deviated is that the clause which states that the client is subject to regulations in the form of new rules, addendum, extension and;/or further amendment made unilaterally by the businesses within the period when client makes use of the service that he/she purchased, namely clause in Article 5 number 2 which stating that: "The amount of interest rate in paragraph (1) of this article, at any time can be changed by the Bank based on interest rate tariff applied in the Bank, which will be notified in written to the Credit Acceptor".

Credit agreement clause as submitted in the agreement above is unfair since the action is done unilaterally by bank. The change in credit interest rate or review for ongoing credit is better on the basis of agreement by both parties, since it is also unfair and unreasonable.

Based on interview conducted by the bank, it can be known that the implementation of provision of Article 18 paragraph (1) letter $f$ and $g$ the Law No. 8 regarding consumer protection related to bank BNl's credit contract in Denpasar branch it can be said that this credit contract is susceptible if not to say deviated. The inclusion of clause which states that bank is entitled to terminate credit term so that the debtor is obliged to pay back in full. Further the clause which states that the change in interest rate that will be notified in written. Clauses which are deviating tend to protect bank position as businesses.

\section{Legal consequence to the standard clause in credit contract is associated with consumer protection.}

In the description of Article 18 paragraph (1) of Consumer Protection Act states that the objective of banning the inclusion of standard clause is that "This prohibition is intended to locate consumer position to be equal to businesses based on the principle of freedom to make contract" so that it is expected with the presence of Article 18 paragraph (1) of Consumer Protection Act will empower consumer from the weaker position in the contract with businesses to become equal in position between businesses and consumer. In order to find out and discuss about legal consequence of bank BNI's credit contract which does not meet the provisions in Consumer Protection Act as mentioned, it needs discussion regarding the terms of validity of any agreement as set in article 1320 of Civil Code. According to Article 1320 of Civil Code (Burgerlijk Wetboek) there are four requirements which must be fulfilled for the validity of any contract, namely:

1. Agreement between the parties binding themselves;

2. Skill to make an agreement;

3. Regarding a specific case;

4. Of any valid cause.

The fourth requirement which closest related to issue associated with bank's credit contract that unsuitable with provision of the Law Number 8 year 1999 concerning Consumer Protection. Not fulfilling one of the elements causing a flaw in the contract, and the contract is threatened with cancelation, either in the form that it can be canceled or null and void, with the understanding that the binding created out of an agreement cannot be enforced for its implementation (Widjaja \& Mulyadi, 2003).

In contract law in Indonesia there is no banning to the agreement with standard clause. The Law No. 8 year 1999 regarding Consumer Protection only bans the usage of some standard clauses in certain cases as outlined in Article 18 paragraph (1). Violation to the provision of Article 18 paragraph (1) of Consumer Protection Act (UUPK) will result in contract made by all parties to be null and void, as in the provision of Article 18 paragraph (3) of UUPK. Agreement with standard clause is not only have legal consequence of null and void if violating the provision of Article 18 paragraph (1) of UUPK. Null and void also 
occurred if agreement with standard clause cannot meet objective requirement, in accordance with the setting in Article 1320 of Civil Code, meanwhile if subjective requirement is met, namely unskillful or free in making the binding then the agreement can be asked to be canceled. The nature of termination of standard contract law does not take place automatically. Article 1266 jo 1267 of Civil Code states that termination of any agreement is through the court and having legal force in the verdict. Null and void of an agreement is a violation to Article 1320 of Civil Code in the term of objective requirement of an agreement. When associated with bank BNI's contract clause, then there are several clauses which susceptible to legal consequence, null and void because violating the provision of Article 18 paragraph (1) of UUPK, that is:

1. The clause of transfer of responsibility, such as in the article related to interest rate which stated that bank can at any time changes the interest rate based on interest rate tariff applied in the Bank, which will be notified in written to Credit Acceptor.

2. The clause to reduce the benefit of a service or decrease the asset of a consumer, such as deviating from a predetermined term in the credit contract, Bank can terminate the term of the credit so that Credit Acceptor is obliged to pay back immediately and in full on the credit which has been withdrawn in the predetermined term in Bank's Notification Letter to Credit Acceptor.

When associated with the freedom to make contract principle in contract law, then the freedom to make credit contract with standard clause cannot be implemented without limit. The limit is provision of Article 18 paragraph (1) of UUPK. Several clauses in bank BNI's credit contract can be categorized as violating the provision of Article 18 paragraph (1) of UUPK but the credit contract can be categorized to have met objective and subjective requirements, as set in Article 1320 of Civil Code. Subjective requirement is related to contract's subject, namely the agreement by all parties in the contract and the skill of all parties in the agreement can be fulfilled since all parties involved in this credit contract have agreed to bind themselves in the contract.

Meanwhile the content of agreement which is created out of an agreement between both parties to become the basis for all parties to achieve the target as well as each other's interest. The utilization of standard clause in the agreement currently cannot be separated from the needs of the businesses who want a quick contract with cheap cost so that can reduce the cost incurred (efficient).

In its implementation the wish to reduce operational cost and shorten the time in making a contract often actually causing a conflict which occurred at the time of contract implementation process. Stewardship and supervision efforts, in this case the responsibility of stewardship is on the government as stipulated in Article 29 the Law No. 8 year 1999, namely:

1. Government is responsible on the stewardship of consumer protection enforcement which warrants acquisition of consumer's rights and businesses' rights as well as the implementation of consumer's and businesses' obligation.

2. Stewardship by government on the enforcement of consumer protection as referred in paragraph (1) is carried out by the Minister and/or relevant technical minister.

3. The minister as referred in paragraph (2) to coordinate on the enforcement of consumer protection.

4. Stewardship of enforcement of consumer protection as referred in paragraph (2) including efforts to:

1. The creation of business climate and the growth of healthy relationship between businesses and consumer;

2. The growth of public independent consumer protection agencies;

3. The increase of human resources' quality as well as the increase of research activities and development in consumer protection field.

4. Further provision regarding the stewardship of enforcement of consumer protection is regulated with Government Regulation. 

Indonesia, Tbk. Denpasar Branch)

Regulation effort for standard clause will not be able to take place when there is not an effort of stewardship and supervision carried out by the government to make a policy that capable to create relationship climate for all parties to going well. With the presence of stewardship it is expected to be able to create strong businesses as well as creating independent consumers and healthy relationship between producer and consumer.

\section{CONCLUSION AND SUGGESTION}

a. Conclusion

1. Implementation of provision of Article 18 paragraph 1 letter $f$ and $g$ the Law No. 8 regarding Consumer Protection related to Bank BNl's credit contract at Denpasar branch, it can be said that this credit contract tends to deviate from the provision because it tends to protect the bank as businesses.

2. Legal consequence of Bank BNI's credit contract which does not meet the provision of Consumer Protection Act as referred to as requirement for validity of any agreement as set in article 1320 of Civil Code will result in null and void.

b. Suggestion

1. It is desirable that the bank in making a credit contract is really implementing the provision of article 18 the Law No. 8 year 1999 regarding Consumer Protection without any exception such as letter $f$ and $g$ so that the bank in formulating bank's credit contract in standard agreement will be based on the balance which does not benefit only one party.

2. Considering all the banks apply standard contract in implementing credit contract, it is better that the clauses which can be standardized to be enforced to all the banks.

\section{REFERENCES}

Badrulzaman, M. D. (1991). Bab-bab Tentang Creditverband, Gadai dan Fiducia. Bandung: Citra Aditya Bakti.

Kristiyanti, C. T. S. (2019). Hukum Perlindungan Konsumen (8th ed.). Jakarta: Sinar Grafika.

Miru, A., \& Yodo, S. (2008). Hukum Perlindungan Konsumen. Jakarta: PT Raja Grafindo Persada.

Muhammad, A. (2006). Hukum dan Penelitian Hukum. Bandung: PT. Citra Aditya Bakti.

Nasution, A. Z. (2002). Hukum Perlindungan Konsumen: Suatu Pengantar. Jakarta: Diadit Media.

Rahmatullah, I. (2015). Aset Hak Kekayaan Intelektual Sebagai Jaminan dalam Perbankan. Jakarta: Deepublish.

Sastrawidjaja, M. S. (2005). Bunga Rampai Hukum Dagang. Bandung: Alumni.

Subekti, R. (1991). Jaminan-jaminan untuk Pemberian Kredit menurut Hukum Indonesia. Bandung: Citra Aditya Bakti.

Sutarno. (2005). Aspek-Aspek Hukum Perkreditan pada Bank. Bandung: Alfabeta.

Suyatno, T., \& Chalik, H. A. (2007). Dasar-dasar Perkreditan. Jakarta: Gramedia Pustaka Utama.

Syawali, H., \& Imaniyati, N. S. (2000). Hukum Perlindungan Konsumen. Bandung: Mandar Maju.

Widjaja, G., \& Mulyadi, K. (2003). Perikatan yang Lahir dari Perjanjian. Jakarta: PT Raja Grafindo Persada.

Undang-Undang No. 8 Tahun 1999 tentang Perlindungan Konsumen 